\title{
KONSTITUSIONALITAS PENGUJIAN PERATURAN DAERAH MELALUIJUDICIAL REVIEW DAN EXECUTIVE REVIEW
}

\author{
Oleh : Dewi Mulyanti, S.H.,M.H.
}

\begin{abstract}
Testing against local regulations has given rise to dualiasme testing i.e. judicial review by the Supreme Court and the executive review by the Central Government. Standard testing rules of the area by the central goverment in contrast to standard testing local regulations by the supreme court. The Supreme Court is testing a rule on the basis of whether or not there is an area of contention with higher regulation and whether there is a discrepancy with the regional lawmaking procedures and regulations while the authority of the Central Government testing regulations area based not only on a rule of law that is higher than the applicable local but also based on the standard of public interest. The cancellation of the local regulations by the Minister of the Interior taken by local governments with a variety of ways, there is an immediate repeal of the regulation in question and the area declared does not apply, but there is also the local Government still enforce applicable local regulations areas that had already been cancelled by the Government regardless of the cancellation giving rise to conditions where local regulations has no enforceability in the Constitution (constitutionality).
\end{abstract}

\begin{abstract}
ABSTRAK
Pengujian terhadap Peraturan Daerah telah melahirkan dualiasme pengujian yaitu judicial review oleh Mahkamah Agungdan executive review oleh pemerintah pusat. Standar pengujian peraturan daerah oleh pemerintah pusat berbeda dengan standar pengujian peraturan daerah oleh Mahkamah Agung. Mahkamah agung menguji suatu peraturan daerah atas dasar ada tidaknya pertentangan dengan peraturan yang lebih tinggi dan ada tidaknya ketidaksesuaian prosedur pembuatan peraturan daerah dengan peraturan perundang-undangan sedangkan kewenangan pemerintah pusat melakukan pengujian peraturan daerah tidak hanya didasarkan pada aturan hukum yang lebih tinggi daripada peraturan daerah tetapi juga didasarkan pada standar kepentingan umum. Pembatalan Peraturan Daerah Oleh Menteri Dalam Negeri ditanggapi oleh Pemerintah Daerah dengan beragam cara, ada yang segera mencabut Peraturan Daerah dimaksud dan dinyatakan tidak berlaku, akan tetapi ada juga pemerintah daerah yang tetap saja memberlakukan Peraturan Daerah -Peraturan Daerah yang sudah dibatalkan oleh pemerintah pusat tersebut tanpa menghiraukan pembatalan tersebut sehingga menimbulkan kondisi dimana peraturan daerah ini tidak memiliki keberlakuan secara konstitusi (konstitusionalitas).
\end{abstract}




\section{Pendahuluan}

Keberadaan Peraturan Daerah tidak dapat dilepaskan kaitannya dengan otonomi daerah (local autonomi). Sebab Peraturan Daerah sebagai perangkat dan salah satu poduk hukum daerah, merupakan sesuatu yang inherent dengan sistem otonomi daerah. Dikatakan demikian, karena esensi otonomi itu sendiri adalah kemandirian (zelfstandigheid) dan bukan sesuatu bentuk kebebasan sebuah satuan pemerintahan yang merdeka (onafhankelijkheid). Kemandirian itu sendiri mengandung arti bahwa daerah berhak membuat keputusan hukum berupa peraturan perundang - undangan yang kemudian (antara lain) diberi nama Peraturan Daerah (Peraturan Daerah ) (I Gde Pantja Astawa, 2008:265) .

Peraturan Daerah adalah nama peraturan perundang undangan tingkat daerah yang ditetapkan Kepala Daerah dengan persetujuan Dewan Perwakilan Rakyat Daerah. Kewenangan Pemerintah Daerah membentuk Peraturan Daerah merupakan salah satu ciri yang menunjukan bahwa pemerintah tingkat daerah tersebut adalah satuan pemerintahan otonom yang berhak mengatur dan mengurus rumah tangga daerahnya sendiri (Bagir Manan, 1992:59$60)$.

Adapun fungsi Peraturan Daerah menurut M. Nur Sholikin (2009:21-22) dalam konteks otonomi daerah adalah sebagai berikut :

1. Peraturan Daerah sebagai beleids instrument dalam melaksanakan otonomi daerah yang luas dan bertanggung jawab. Pada fungsi ini, 
Peraturan Daerah sebagai sarana hukum yaitu alat untuk melaksanakan kebijakan daerah dalam melaksanakan otonomi daerah dan tugas pembantuan.

2. Peraturan Daerah merupakan pelaksana peraturan perundang undangan yang lebih tinggi. Dalam fungsi ini Peraturan Daerah tunduk pada asas peraturan perundang - undangan dimana Peraturan Daerah tidak boleh bertentangan dengan peraturan yang lebih tinggi.

3. Peraturan Daerah sebagai alat penangkap dan penyalur aspirasi daerah. Dalam fungsi ini Peraturan Daerah merupakan sarana penyalur kondisi khusus daerah dalam konteks ekonomi, politik dan sosial. Peran serta aktif masyarakat sangat dibutuhkan agar aspirasi masyarakat dapat tertampung dan tersalurkan dengan baik.

4. Peraturan Daerah sebagai alat transformasi daerah. Peraturan Daerah diharapkan bisa mengubah institusi dan prilaku bermasalah dari objek yang diaturnya. Melalui perubahan tersebut ada transformasi dari masyarakat yang selama ini terbebani oleh perilaku bermasalah tersebut.

5. Peraturan Daerah sebagai harmonisator berbagai kepentingan. Dalam fungsi ini Peraturan Daerah merupakan produk pertemuan berbagai kepentingan. Oleh karena itu dalam pembentukan Peraturan Daerah, Dewan Perwakilan Rakyat Daerah dan Pemerintah Daerah harus bisa memperhitungkan kepentingan dari 
para pemangku kepentingan dan warga yang terkena imbas pemberlakuan Peraturan Daerah.

Kewenangan daerah dalam pembentukan produk hukum daerah merupakan konsekuensi logis atau bahkan dapat dikatakan sebagai prasyarat mutlak (conditio sine qua non) dari adanya otonomi daerah, yang salah satu dimensinya merupakan kewenangan daerah untuk melakukan pengaturan (regeling), selain dimensi kewenangan mengurus/mengelola (bestuur) pemerintahan.

Pada tataan teoritik, pembentukan peraturan perundang undangan (termasuk Peraturan Daerah) yang layak atau berkualitas ditentukan oleh pemenuhan terhadap beberapa syarat yaitu asas asas pembentukan dan materi muatan, kesesuaian antara jenis peraturan dengan materi muatan, adanya landasan pembentukan, tahapan pembentukan dan kerangka perundang - undangan.

Dalam konteks Indonesia, asas-asas pembentukan perundangundangan diatur dalam Pasal 5 dan Pasal 6 Undang- Undang Nomor 12 Tahun 2011 Tentang Pembentukan Peraturan PerundangUndangan junctoPasal 237 ayat (1) Undang-Undang Nomor 23 Tahun 2014 Tentang Pemerintahan Daerah meliputi asas-asas pembentukan meliputi : (a) kejelasan tujuan; (b) kelembagaan atau organ pembentuk yang tepat; (c) kesesuaian antara jenis dan materi muatan; (d) dapat dilaksanakan (e) kedayagunaan dan kehasilgunaan (f) kejelasan rumusan; dan (g) keterbukaan. Sedangkan asas - asas materi muatan perundang - undangan meliputi : (a) pengayoman; (b) kemanusiaan; 
(c) kebangsaan (d) kekeluargaan; (e) kenusantaraan; (f) bhineka tunggal ika; (g) keadilan; (h) kesamaan kedudukan dalam hukum dan pemerintahan; (i) ketertiban dan kepastian hukum; dan (j) keseimbangan, keserasian dan keselarasan.

Dalam rangka mendorong penyelenggaraan otonomi daerah, setiap penyelenggara pemerintahan daerah dituntut untuk memahami tertib regulasi, utamanya dalam pembentukan produk hukum daerah. Tertib regulasi adalah suatu proses membuat produk hukum yang baik sesuai dengan peraturan perundang - undangan dan kepentingan umum yang terdiri dari unsur tertib kewenangan, tertib prosedur, tertib substansi dan tertib implementasi. Melalui pemahaman tertib regulasi yang baik, maka akan dapat membuat produk hukum daerah yang berkualitas dan efektif (Zudan Arif, 2013:2-3).

Meskipun dalam tataran teoritik dan normatif telah diatur persyaratan pembentukan peraturan perundang - undangan yang baik dan layak, namun dalam tataran empirik, oleh karena peraturan perundang - undangan tersebut merupakan hasil karya manusia tidak akan terlepas atau terhindar dari kekurangan dan ketidaksempurnaan. Oleh karenanya terbuka peluang untuk melakukan pengujian (review) terhadap peraturan perundang - undangan. Menurut Jimly Asshiddiqie untuk menjamin konsistensi antar peraturan, dimungkinkan adanya mekanisme judicial reviewatau pengujian materi peraturan terhadap peraturan yang lebih tinggi (Jimly Asshiddiqie, 2006:303). 
Adanya pengujian terhadap peraturan daerah yang dilakukan oleh pemerintah tidak sepenuhnya diterima baik oleh daerah-daerah, pada kenyataannya banyak daerah yang merasa keberatan jika peraturan daerah yang telah dibuat dengan susah payah, membutuhkan biaya yang banyak dan waktu yang lama dan melibatkan wakil rakyat pada Dewan Perwakilan Rakyat Daerah pada akhirnya dibatalkan oleh Menteri Dalam Negeri,sehinga mereka berpendapat oleh karena peraturan daerah yang sudah disahkan dan dibuat dengan cara yang benar untuk kepentingan rakyat, tidak begitu saja dapat dibatalkan dan seandainya dibatalkan pun harus melalui prosedur hukum yang sesuai dengan hierarki pembentukan peraturan perundang-undangan.

Berdasarkan latar belakang tersebut permasalahannya adalah bagaimanakah mekanisme secara konstitusi atau konstitusionalitas dalam pengujian Peraturan Daerah melalui judicial review dan executive review?

Penulisan ini bertujuan untuk mengetahui mekanisme secara konstitusi atau konstitusionalitas dalam pengujian Peraturan Daerah baik alasan pengujian, pengaturan pengujian, dasar pengujian maupun bentuk hukum hasil pengujian Peraturan Daerah tersebut. Sehingga diharapkan dapat memberikan wawasan pengetahuan bagi pembaca khususnya 
mengenai pengujian Peraturan Daerah melalui judicial review dan executive review.

\section{Tinjauan Pustaka}

\subsection{Istilah, Hakekat dan Tujuan Otonomi Daerah}

Secara etimologis, istilah "autonomy" berasal dari bahasa Yunani, terdiri dari "auto" yang berarti sendiri dan "nomous" yang berarti hukum atau peraturan. Dalam literatur Belanda, otonomi berarti zelfregering (pemerintahan sendiri), yang oleh Van Vollenhoven dibagi menjadi zelfwetgeving (membuat undang undang sendiri), zelfuitvoering (melaksanakan sendiri), zelfrechtspraak (mengadili sendiri) dan zelfpolitie (menindak sendiri). Sementara Van der pot memahami konsep otonomi daerah sebagai eigenhuisholding (menjalankan rumah tangganya sendiri) (Laica Marzuki, 2005:125) .

Otonomi daerah merupakan pemberian kebebasan untuk mengurus rumah tangga sendiri, tanpa mengabaikan kedudukan Pemerintah Daerah sebagai aparat Pemerintah Pusat untuk menyelenggarakan urusan - urusan yang ditugaskan kepadanya.

Berikut ini pengertian otonomi daerah menurut para ahli (syamsuddin Haris, 2007:12-13) adalah sebagai berikut :

\section{F. Sugeng Istianto}

Menurut Sugeng Istianto menyatakan bahwa Otonomi daerah ialah suatu Hak dan wewenang guna untuk mengatur serta mengurus sebuah rumah tangga daerah. 
2. Ateng Syarifuddin

Menurut Ateng Syarifuddin menyatakan bahwa Otonomi daerah mempunyai makna kebebasan atau kemandirian namun bukan kemerdekaan melainkan hanya suatu kebebasan yang terbatas atau kemandirian itu terwujud sebagai sebuah pemberian kesempatan yang harus dapat dipertanggungjawabkan.

\section{Syarif Saleh}

Menurut Syarif Saleh menyatakan bahwa Otonomi daerah ialah suatu hak mengatur serta memerintah daerah sendiri dimana hak tersebut ialah hak yang diperoleh dari suatu pemerintah pusat.

4. Kansil

Menurut Kansil menyatakan bahwa Otonomi daerah ialah suatu hak, dan wewenang, serta kewajiban daerah untuk mengatur serta untuk mengurus rumah tangganya atau daerahnya sendiri sesuai dengan perundang-undangan yang masih berlaku.

\section{Widjaja}

Menurut Widjaja menyatakan bahwa Otonomi daerah ialah salah satu bentuk dari desentralisasi suatu pemerintahan yang dasarnya ditujukan guna untuk memenuhi suatu kepentingan bangsa secara menyeluruh, ialah suatu upaya yang lebih mendekatkan berbagai tujuan untuk penyelenggaraan pemerintahan sehingga dapat mewujudkan suatu cita-cita masyarakat yang adil dan makmur. 


\section{Mahwood}

Menurut Mahwood menyatakan bahwa Otonomi daerah ialah suatu hak dari masyarakat sipil guna untuk mendapatkan sebuah kesempatan serta perlakuan yang sama, baik dalam hal mengekspresikan serta memperjuangkan suatu kepentingan mereka masing-masing, dan ikut mengontrol sebuah penyelenggaraan kinerja pemerintahan daerah.

7. Benyamin Hoesein

Menurut Benyamin Hoesein menyatakan bahwa otonomi daerah adalah suatu pemerintahan oleh rakyat serta untuk rakyat di suatu bagian wilayah nasional Negara secara informal yang berada diluar pemerintah pusat.

8. Mariun

Menurut Mariun menyatakn bahwa Otonomi daerah ialah suatu kebebasan atau kewenangan yang dipunyai suatu pemerintah daerah sehingga memungkinkan mereka dalam membuat sebuah inisiatif sendiri untuk mengelola serta mengoptimalkan sumber daya yang dipunyai daerahnya. Otonomi daerah ialah suatu kebebasan atau kewenangan untuk dapat bertindak sesuai dengan suatu kebutuhan masyarakat pada daerah setempat.

9. Vincent Lemius

Menurut Vincent Lemius menyatakan bahwa Otonomi daerah ialah suatu kebebasan atau kewenangan dalam membuat 
suatu keputusan politik maupun administasi yang sesuai dengan yang ada didalam peraturan perundang- undangan. $\mathrm{Di}$ dalam suatu otonomi daerah terdapat sebuah kewenangan yang dipunyai oleh suatu pemerintah daerah dalam menentukan apa yang menjadi suatu kebutuhan daerahnya namun kebutuhan daerah yang lain masih senantiasa harus disesuaikan dengan suatu kepentingan nasional sebagaimana diatur peraturan perundang-undangan yang lebih tinggi.

10. Encyclopedia of Social Scince

Menurut Encyclopedia of Social Scince menyatakan bahwa otonomi daerah ialah suatu hak sebuah organisasi sosial untuk mencukupi diri sendiri dan sebuah kebebasan aktualnya.

Hakekat otonomi daerah adalah pemberian wewenang kepada daerah untuk mengatur dan mengurus rumah tangga daerah dalam upaya mewujudkan kesejahteraan masyarakat. Otonomi juga diartikan sebagai sesuatu yang bermakna kebebasan atau kemandirian (zelfstandigheid) tetapi bukan kemerdekaan (onafhankelijkheid). Kebebasan yang terbatas atau kemandirian itu adalah wujud pemberian kesempatan yang harus dipertanggungjawabkan (Ateng Syafrudin, 1985:5).

Tujuan pemberian otonomi kepada daerah setidaknya meliputi beberapa aspek :

a. Dari segi politik adalah untuk mengikutsertakan, menyalurkan inspirasi dan aspirasi masyarakat, baik untuk 
kepentingan daerah sendiri, maupun untuk mendukung politik dan kebijaksanaan nasional dalam rangka pembangunan dalam proses demokrasi di lapisan bawah.

b. Dari segi manajemen pemerintahan, adalah untuk meningkatkan daya guna dan hasil guna penyelenggaraan pemerintahan, terutama dalam memberikan pelayanan terhadap masyarakat dengan memperluas jenis - jenis pelayanan dalam berbagai kebutuhan masyarakat.

c. Dari segi kemasyarakatan, untuk meningkatkan partisipasi serta menumbuhkan kemandirian masyarakat, dengan melakukan usaha pemberdayaan (empowerment) masyarakat, sehingga masyarakat makin mandiri, dan tidak terlalu banyak tergantung pada pemberian pemerintah serta memiliki daya saing yang kuat dalam proses penumbuhannya.

d. Dari segi ekonomi pembangunan, adalah untuk melancarkan pelaksanaan program pembangunan guna tercapainya kesejahteraan rakyat yang makin meningkat. 


\subsection{Hubungan Pengawasan Pemerintah Pusat dengan} Pemerintah Daerah

Dalam sistem negara kesatuan ditemukan adanya 2 cara yang dapat menghubungkan antara Pemerintah Pusat dan Daerah. Cara pertama disebut sentralisasi dimana segala urusan, tugas, fungsi dan wewenang penyelenggaraan pemerintahan ada pada pemerintah pusat yang pelaksanaannya dilakukan secara dekonsentrasi. Cara kedua, dikenal sebagai desentralisasi, dimana urusan, tugas dan wewenang pelaksanaan pemerintahan diserahkan seluas - luasnya kepada daerah.

Meskipun sentralisasi dan desentralisasi dapat dibedakan, namun tidak dapat dilakukan pemisahan secara tegas karena memiliki keterkaitan satu sama lain. Jadi prinsipnya tidak mungkin diselenggarakan desentralisasi tanpa sentralisasi, karena akan berdampak pada disintegrasi. Oleh sebab itu, otonomi daerah yang hakekatnya mengandung kebebasan dan keleluasaan prakarsa, akan selalu memerlukan bimbingan dan pengawasan pemerintah pusat, sehingga tidak menjelma menjadi kedaulatan otonomi daerah. Otonomi daerah adalah ciptaan pemerintah pusat.

Oleh karena otonomi daerah tidak bermakna kebebasan atau kemerdekaan daerah, maka pemberian dan pelimpahan kewenangan kepada daerah disertai adanya pengawasan dari pemerintah pusat. Dalam hal ini pengawasan merupakan unsur 
yang tidak dapat dipisahkan dari kebebasan berotonomi. Antara kebebasan dan kemandirian berotonomi di satu pihak dengan pengawasan di pihak lain, merupakan dua sisi dalam satu mata uang dalam negara kesatuan dengan sistem otonomi (desentralisasi). Kebebasan dan kemandirian berotonomi dapat dipandang sebagai pengawasan atau kendali terhadap kecenderungan sentralisasi yang berlebihan. Sebaliknya, pengawasan merupakan kendali terhadap desentralisasi yang berlebihan. Tidak ada otonomi tanpa pengawasan (geen otonomi zonder toetzicht) (Bagirmanan, 1992:26).

Dalam konteks negara demokrasi dan negara kesatuan, pengawasan terhadap aktivitas pemerintah, baik yang dilakukan pemerintah pusat dan pemerintah daerah merupakan hal yang mutlak. Jimly Asshiddiqie secara tegas mengemukakan urgensi pengawasan dalam konteks negara kesatuan sebagai berikut : " dalam perspektif sistem negara kesatuan atau unitary state (eenheidsstaat) adalah logis untuk mengembangkan pengertian bahwa pemerintahan atasan berwenang melakukan kontrol terhadap unit pemerintahan bawahan. Artinya pemerintahan pusat dalam konteks Negara Kesatuan Republik Indonesia berdasarkan Undang - Undang Dasar Negara Republik Indonesia Tahun 1945 tentu dapat dikatakan mempunyai kewenangan untuk mengontrol unit - unit pemerintahan daerah provinsi ataupun pemerintahan daerah kabupaten dan kota. Demikian pula pemerintahan daerah 
provinsi juga dapat diberi kewenangan tertentu dalam rangka mengendalikan jalannya pemerintahan daerah kabupaten dan kota di bidang pengaturan.

Paulus Effendie Lotulung mengemukakan bahwa tujuan utama dilakukannya pengawasan terhadap pemerintah adalah untuk menghindari terjadinya kekeliruan-kekeliruan, baik yang disengaja maupun tidak disengaja, sebagai suatu usaha preventif atau juga untuk memperbaikinya apabila sudah terjadi kekeliruan itu, sebagai usaha represif.

Lebih lanjut, pengawasan dapat diklasifikasikan dalam beberapa hal, tergantung tolok ukur yang digunakan. Berkenaan dengan lingkup pengawasan, Bagir Manan mengemukakan dua jenis pengawasan baku terhadap satuan pemerintahan otonomi yaitu pengawasan preventif (preventief toezicht) dan pengawasan represif (repressief toezicht). Pengawasan prevenif dikaitkan dengan wewenang mengesahkan, sementara pengawasan represif berkenaan dengan wewenang pembatalan (vernietiging) atau penanggulan (schorsing).

Klasifikasi berdasarkan lingkup pengawasan mempunyai kemiripan dengan klasifikasi berdasarkan waktu pelaksanaan pengawasan. Paulus Effendi Lotulung membedakan menjadi dua jenis yaitu kontrol a-priori dan kontrol a-posteriori. Kontrol a-priori adalah pengawasan yang dilakukan sebelum dilakukan tindakan atau dikeluarkannya suatu keputusanatau 
ketetapan pemerintah atau peraturan lainnya yang menjadi wewenang pemerintah. Pengawasan ini mengandung unsur pengawasan preventif. Kontrol a-posteriori adalah pengawasan yang dilakukan sesudah dikeuarkan suatu keputusan atau ketetapan pemerintah atau sesudah terjadinya tindakan pemerintah. Pengawasan ini mengandung unsur pengawasan represif yang bertujuan mengoreksi tindakan yang keliru (Paulus Effendie Lotulung, 1993:15-16).

Penggolongan pengawasan dari tolok ukur kelembagaan yang dikontrol dan yang melaksanakan kontrol, dibedakan menjadi kontrol intern (internal control) dan kontrol ekstern (external contro). Kontrol intern adalah pengawasan yang dilakukan oleh suatu badan/organ yang secara struktural masih termasuk organisasi dalam lingkungan pemerintah. Misalnya pengawasan yang dilakukan oleh pejabat atasan terhadap bawahannya secara hierarkhis. Sedangkan kontrol ekstern adalah pengawasan yang dilakukan oleh badan/organ secara struktur organisasi berada di luar pemerintah dalam arti eksekutif. Misalnya kontrol keuangan yang dilakukan oleh BPK, kontrol sosial yang dilakukan oleh LSM, media masa, kontrol politik yang dilakukan oleh DPR dan DPRD, serta kontrol peradilan oleh peradilan umum dan peradilan administrasi.

Selanjutnya klasifikasi pengawasan dari aspek yang diawasi dibedakan menjadi pengawasan segi hukum dan 
pengawasan segi kemanfaatan. Pengawasan segi hukum (legalitas) yaitu pengawasan yang dimaksudkan untuk menilai segi-segi hukumnya saja (rechmatigheid). Kontrol peradilan atau judicial control secara umum dipandang sebagai pengawasan segi hukum walaupun ada perkembangan baru yang mempersoalkan pembatasan itu. Pengawasan dari segi kemanfaatan (opportunitas) yaitu pengawasan yang dimaksudkan untuk menilai segi kemanfaatannya (doelmatigheid).

Terkait substansi pengawasan dalam konteks negara kesatuan, Jimly Asshiddiqie mengemukakan bahwa yang dikendalikan atau dikontrol oleh pemerintahan atasan itu antara lain adalah kontrol atas norma hukum yang ditetapkan oleh pemerintahan bawahan melalui apa yang dinal sebagai "general norm control mechanism". Mekanisme kontrol norma umum inilah yang biasa disebut dengan sistem "abstract review" atau pengujian abstrak yang dapat dilakukan oleh lembaga eksekutif, lembaga legislatif ataupun oleh lembaga peradilan. Disamping "abstract review" mekanisme kontrol norma dapat dilakukan melalui prosedur "abstrak preview", yaitu kontrol yang dilakukan sebelum norma hukum yang bersangkutan mengikat untuk umum. Misalnya, setelah suatu rancangan undang-undang disahkan oleh parlemen, tetapi sebelum diundangkan sebagai mestinya, pemerintahan atasan diberikan kewenangan untuk menguji, 
menilai, atau bahkan menolak pengesahan peraturan pemerintahan bawahan (Bagirmanan, 2001:154).

Bertolak dari uraian di atas, pengawasan terhadap produk hukum daerah, terutama pembentukan Peraturan Daerah merupakan hal yang tidak dapat dihindari karena lingkup atau satuan pemerintahan daerah merupakan bagian dari satuan pemrintah pusat. Oleh karenanya, pembentukan norma hukum atau peraturan perundang-undangan di daerah perlu memeprhatikan keterkaitannya dengan peraturan perundangundangan pada jenjang yang lebih tinggi, sebagaimana diatur dalam hirarki peraturan perundang-undangan Indonesia.

\subsection{Teori Pengujian Perundang-Undangan}

Secara etimologis, pengujian norma atau pengujian peraturan perundang-undangan dikenal dengan beberapa istilah seperti toetsingrecht, constitutional review, legislative review, executive review dan judicial review. Toetsingrechtberarti hak menguji sedangkan judicial reviemberarti peninjauan kembali oleh lembaga pengadilan.

Jika hak uji (toetsingrecht) diberikan kepada hakim, maka namanya adalah judicial review atau review oleh lembaga peradilan. Jika kewenangan untuk menguji itu diberikan kepada lembaga legislatif, maka namanya legislative review. Jika yang melakukan pengujian itu adalah pemerintah maka namanya adalah executive review. 
Istilah judicial reviewterbatas penggunaannya kepada proses uji perundang - undangan yang dilakukan oleh lembaga peradilan. Constitutional reviewdigunakan secara umum terhadap proses uji konstitusionalitas produk perundang - undangan yang berada di bawah konstutusi yang dilakukan oleh lembaga legislatif ataupun lembaga peradilan bahkan oleh sebuah lembaga khusus yang ditunjuk untuk melakukan tugas uji konstitusional tersebut(I Gde Pantja Astawa, 2008:117).

Pentingnya Constitutional review atau pengujian peraturan perundang - undangan dalam sebuah negara merupakan konsekuensi dianutnya paham negara hukum dan ajaran supremasi hukum. Terkait dengan pengujian perundang undangan , Sri Soemantri (1982:5-6) menggolongkan hak menguji menjadi dua macam yaitu :

a. Hak menguji formal (formeletoetsingrecht) adalah wewenang untuk menilai suatu produk legislatif seperti undang - undang terkait legalitas kompetensi institusi yang membuatnya.

b. Hak menguji materiil (materieletoetsingrecht) adalah suatu wewenang untuk menyelidiki dan menilai isi apakah suatu peraturan perundang - undangan sesuai atau bertentangan dengan peraturan perundang - undangan yang lebih tinggi derajatnya, serta apakah suatu kekuasaan tertentu berhak mengeluarkan suatu peraturan tertentu. Pengujian secara meteriil berkaitan dengan kemungkinan pertentangan materi 
suatu peraturan dengan peraturan lain yang lebih tinggi ataupun menyangkut kekhususan - kekhususan yang dimiliki suatu aturan dibandingkan dengan norma - norma yang berlaku umum.

\section{Pembahasan}

Selama ini kategori Peraturan Daerah yang bermasalah merujuk pada dua hal penting, yaitu Peraturan Daerah yang bertentangan dengan kepentingan umum, dan Peraturan Daerah yang bertentangan dengan peraturan perundang-undangan lebih tinggi. secara teoritis, suatu Peraturan Daerah dikatakan bertentangan dengan kepentingan umum apabila pemberlakuan Peraturan Daerah tersebut berakibat terganggunya kerukunan antar warga masyarakat, pelayanan umum, dan ketentraman/ketertiban umum. Bisa pula karena kebijakan yang tertuang di dalamnya bersifat diskriminatif. Jadi, dapat diyakini, apabila dipaksakan keberlakuannya maka akan menimbulkan konflik di masyarakat. Sedangkan Peraturan Daerah yang bertentangan dengan peraturan perundang-undangan yang lebih tinggi adalah Peraturan Daerah yang baik prosedur pembentukan dan atau isinya bertentangan dengan Peraturan Pemerintah, Undang-Undang, dan peraturan peraturan perundang-undangan lain yang dalam tata urutan berada di atas Peraturan Daerah .

Peraturan Daerah memiliki peran yang penting dalam melaksanakan urusan pemerintahan. Peraturan Daerah memiliki 
kedudukan di bawah undang - undang tetapi sampai saat ini masih menjadi perdebatan mengenai hak menguji Peraturan Daerah karena berlaku judicial review dan executive review.

Ada dua mekanisme pembatalan Peraturan Daerah yakni :

a. Judicial revie.

Pembatalan yang dilakukan oleh Mahkamah Agung (MA) dengan cara uji materiil yaitu menilai materi muatan peraturan perundang - undangan di bawah undang - undang terhadap peraturan perundang - undangan lebih tinggi.

Jika inisiatif untuk melakukan pengujian terhadap suatu perundang-undangan ini datang bukan dari MA, maka disebut dengan Permohonan Keberatan. Permohonan Keberatan adalah suatu permohonan yang berisi keberatan terhadap berlakunya suatu peraturan perundang-undangan yang diduga bertentangan dengan suatu peraturan perundang-undangan tingkat lebih tinggi yang diajukan ke MA untuk mendapatkan putusan.

Merujuk pada penjelasan di atas, terhadap suatu Peraturan Daerah kabupaten/kota yang diduga bertentangan dengan Peraturan Daerah provinsi, selain dapat dilakukan uji materiil oleh MA, dapat juga dimohonkan suatu keberatan secara langsung kepada MA, atau dapat disampaikan melalui Pengadilan Negeri yang membawahi wilayah tempat kedudukan Pemohon.Contoh Peraturan Daerah yang pernah diuji ke MA, adalah Pasal 30 Peraturan Daerah Khusus Provinsi Papua Nomor 6 Tahun 2011 
tentang Pemilihan Umum Gubernur dan Wakil Gubernur. Melalui

Putusan Mahkamah Agung Nomor 16 P/Hum/2012 Tahun 2012, MA mencabut Peraturan Daerah Nomor 6 Tahun 2011 tentang Pemilihan Umum Gubernur dan Wakil Gubernur.

b. Executive review

Pembatalan dilakukan oleh Menteri atau Gubernur. Untuk Peraturan Daerah kabupaten/kota yang bertentangan dengan Peraturan Daerah provinsi (sebagai peraturan perundangundangan yang lebih tinggi dari Peraturan Daerah kabupaten/kota), gubernur berwenang untuk membatalkan Peraturan Daerah kabupaten/kota tersebut dengan keputusan gubernur.

Pembatalan yang dilakukan oleh Menteri apabila Peraturan Daerah provinsi dan Peraturan Gubernur yang bertentangan dengan ketentuan peraturan perundang-undangan yang lebih tinggi, kepentingan umum, dan/atau kesusilaan dibatalkan oleh Menteri.Pembatalan Peraturan Daerah Provinsi dan Peraturan Gubernur ditetapkan dengan Keputusan Menteri.Paling lama 7 hari setelah keputusan pembatalan, kepala daerah harus menghentikan pelaksanaan Peraturan Daerah dan selanjutnya DPRD bersama kepala daerah mencabut Peraturan Daerah dimaksud.

Sedangkan pembatalan dilakukan oleh Gubernur, Peraturan Daerah kabupaten/kota dan peraturan bupati/wali kota yang bertentangan dengan ketentuan peraturan perundang-undangan 
yang lebih tinggi, kepentingan umum, dan/atau kesusilaan dibatalkan oleh Gubernur sebagai wakil Pemerintah Pusat. Pembatalan Peraturan Daerah Kabupaten/Kota dan peraturan bupati/wali kota ditetapkan dengan keputusan gubernur sebagai wakil Pemerintah Pusat.

Paling lama 7 hari setelah keputusan pembatalan, kepala daerah harus menghentikan pelaksanaan Peraturan Daerah dan selanjutnya DPRD bersama kepala daerah mencabut Peraturan Daerah dimaksud. Berdasarkan uraian di atas, terhadap Peraturan Daerah kabupaten/kota yang bertentangan dengan Peraturan Daerah provinsi dapat dilakukan pembatalan dengan Keputusan Gubernur.

Dalam hal penyelenggara Pemerintahan Daerah provinsi tidak dapat menerima keputusan pembatalan Peraturan Daerah provinsi dan Gubernur tidak dapat menerima keputusan pembatalan Peraturan Gubernur dengan alasan yang dapat dibenarkan oleh ketentuan peraturan perundang-undangan, Gubernur dapat mengajukan keberatan kepada Presiden paling lambat 14 hari sejak keputusan pembatalan Peraturan Daerah atau Peraturan Gubernur diterima.

Sedangkan dalam hal penyelenggara Pemerintahan Daerah kabupaten/kota tidak dapat menerima keputusan pembatalan Peraturan Daerah kabupaten/kota dan Bupati/Walikota tidak dapat menerima keputusan pembatalan Peraturan Bupati/Walikota 
dengan alasan yang dapat dibenarkan oleh ketentuan peraturan perundang-undangan, Bupati/Walikota dapat mengajukan keberatan kepada Menteri paling lambat 14 hari sejak keputusan pembatalan Peraturan Daerah Kabupaten/Kota atau Peraturan Bupati/Walikota diterima.

Penyelenggara Pemerintahan Daerah provinsi atau kabupaten/kota yang masih memberlakukan Peraturan Daerah yang dibatalkan oleh Menteri atau oleh Gubernur dikenai sanksi berupa:

a. Sanksi administratif

Dikenai kepada kepala Daerah dan anggota DPRD berupa tidak dibayarkan hak-hak keuangan yang diatur dalam ketentuan peraturan perundang-undangan selama 3 (tiga) bulan.

b. Sanksi penundaan evaluasi rancangan Peraturan Daerah

Dalam hal penyelenggara Pemerintahan Daerah provinsi atau kabupaten/kota masih memberlakukan Peraturan Daerah mengenai pajak daerah dan/atau retribusi daerah yang dibatalkan oleh Menteri atau dibatalkan oleh Gubernur sebagai wakil Pemerintah Pusat, dikenai sanksi penundaan atau pemotongan Dana Alokasi Umum (DAU) dan/atau Dana Bagi Hasil (DBH) bagi Daerah bersangkutan. 


\section{Kesimpulan}

Pengujian terhadap Peraturan Daerah telah melahirkan dualiasme pengujian yaitujudicial review oleh Mahkamah Agung dan executive review oleh pemerintah pusat. Mahkamah agung menguji suatu peraturan daerah atas dasar ada tidaknya pertentangan dengan peraturan yang lebih tinggi dan ada tidaknya ketidaksesuaian prosedur pembuatan peraturan daerah dengan peraturan perundang-undangan sedangkan kewenangan pemerintah pusat melakukan pengujian peraturan daerah tidak hanya didasarkan pada aturan hukum yang lebih tinggi daripada peraturan daerah tetapi juga didasarkan pada standar kepentingan umum.

Perdebatan mengenai berlakunya pengujian pembatalan terhadap Peraturan Daerah menjadi pertanyaan tersendiri di era otonomi daerahini, mengingat Peraturan Daerah adalah produk kepala daerah dan DPRD di suatudaerah yang bersifat otonom sedangkan salah satu dampak positifberkembangnya ide otonomi daerah adalah menguatnya eksistensi Peraturan Daerah sebagai produk legislatif daerah yang memungkinkan pengembangan segala potensi kekhasan daerah mendapat payung yuridis yang jelas.Sebagian kalangan memandang Peraturan Daerah merupakan Local Wet, yang mempunyai prototipe yang sebangun dengan Undang-Undang (Wet) di tingkat pusat. Dilihat dari ruang lingkup materi muatan, cara perumusan, pembentukan dan pengundangannya, kedudukannya dalam tata urutan (hirarkis) peraturan perundang-undangan 
pembentukan dan pengundangannya, kedudukannya dalam tata urutan serta daya berlakunya sebagai norma hukum, sebagaimana ditentukan dalam Undang-Undang Nomor 12 Tahun 2011 tentang Pembentukan Peraturan Perundang-undangan memang pandangan yang melihat hal ini sebagai produk hukum yang mandiri tidak berlebihan.

\section{Saran}

Saran penulis, untuk diperhatikan dan ditindaklanjuti mengenai hal- hal berikut ini :

1. Undang-Undang Pemerintahan Daerah menyatakan bahwa pembatalan Peraturan Daerah ditetapkan dengan Peraturan Presiden paling lama 60 (enam puluh hari) sejak diterimanya Peraturan Daerah oleh pemerintah pusat, evaluasi Peraturan Daerah oleh pemerintah pusat tetap memakan waktu yang lama. Lamanya proses evaluasi Peraturan Daerah oleh pemerintah berimplikasi pada terabainya kepastian hukum penerapan Peraturan Daerah di daerah.

2. Tidak tertibnya evaluasi Peraturan Daerah oleh pemerintah pusat bermula dari tidak lengkapnya dan segeranya Peraturan Daerah disampaikan oleh pemerintah daerah kepada pemerintah pusat setelah Peraturan Daerah disahkan di daerah. Tidak tertibnya pendokumentasian Peraturan Daerah ini terjadi karena 3 (tiga) hal, yaitu: 
a. Ketidaktahuan pemerintah daerah bahwa ada kewajiban mereka untuk menyerahkan Peraturan Daerah kepada pemerintah pusat.

b. Keengganan pemerintah daerah menyerahkan Peraturan Daerah kepada pemerintah pusat karena tidak adanya sanksi bagi daerah yang tidak menyerahkannya.

c. Untuk menghindari sanksi berupa pembatalan Peraturan Daerah oleh pemerintah pusat karena bila Peraturan Daerah tersebut dinilai bertentangan dengan peraturan perundangundangan yang lebih tinggi oleh pemerintah pusat maka Peraturan Daerah tersebut akan dibatalkan.

3. Hal yang paling janggal dalam pengujian Peraturan Daerah oleh pemerintah adalah soal bentuk hukum pembatalan Peraturan Daerah. Bentuk hukum pembatalan Peraturan DaerahPeraturan Presiden. Namun dalam praktiknya, Pembatalan Peraturan Daerah sepanjang ini dilakukan dengan menggunakan Keputusan Menteri Dalam Negeri (Kepmendagri). Dengan demikian, pembatalan Peraturan Daerah melalui (Kepmendagri) merupakan sebuah kekeliruan hukum. 


\section{DAFTAR PUSTAKA}

Asshiddiqie. Jimly, 2006, Konstitusi dan Konstitusionalisme Indonesia, Konstitusi Pers, Jakarta.

-------, 2008, Dinamika dan IImu Perundang - undangan Di Indonesia, PT. Alumni, Bandung.

-------, 2008, Poblematika Hukum Otonomi Daerah Di Indonesia, PT. Alumni, Bandung.

Bagir Manan, 1992, Dasar - Dasar Perundang - Undangan Indonesia, Ind-Hill.Co, Jakarta.

--------, 2001, Menyongsong Fajar Otonomi Daerah, PSH FH UII, Yogyakarta.

Fakrulloh. Zudan Arif, 2013, Tertib Regulasi Dalam Penyusunan Produk Hukum Daerah, Biro Hukum Kemendagri RI, 2013.

Lotulung, Paulus Effendie, 1993, Beberapa Sistem tentang Kontrol Segi Hukum Terhadap Pemerintah, Citra Aditya Bakti, Bandung.

Marzuki. HM. Laica, 2005, Berjalan - jalan di Ranah Hukum, Pikiran Pikiran Lepas, Konpress, Jakarta.

Sholikin. M.Nur, 2009, Awasi Peraturan Daerah , Berdayakan Daerah Seri Panduan Pemantauan Legislasi Daerah, Pusat Studi Hukum \& Kebijakan Indonesia (PSHK), Jakarta.

Soemantri M. Sri, 1982, Hak Menguji Materiil Di Indonesia, Alumni, Bandung.

Syafrudin. Ateng, 1985, Pasang Surut Otonomi Daerah, Binacipta, Bandung.

Syamsuddin. Haris, 2007, Desentralisasi dan Otonomi Daerah, LIPI Press, Jakarta. 